The Leadership Quarterly, Volume 19, Issue 1, February 2008, Pages 31-41

Leading Beautifully: How Mastery, Congruence and Purpose Create the Aesthetic of Embodied Leadership Practice

\author{
Dr Donna Ladkin \\ Cranfield School of Management \\ Cranfield University \\ Cranfield \\ Beds MK43 OAL \\ Donna.Ladkin@cranfield.ac.uk
}




\title{
Leading Beautifully: How Mastery, Congruence and Purpose Create the Aesthetic of Embodied Leadership Practice
}

\begin{abstract}
This paper explores the territory of leading as an embodied activity through the lens of the aesthetic category of 'the beautiful'. Its starting point is that although much of the literature about effective leadership practice focuses on leadership behaviours, little is written about the way in which those behaviours are actually enacted. The musician, Bobby McFerrin serves as a case study for identifying three key aspects of leading beautifully: mastery, congruence between form and content, and purpose. These are further considered through reference to the concept of beauty as theorised by the philosophers Plato and Plotinus. The paper then considers how 'leading beautifully' might differ from other conceptualisations of leadership and discusses the particular insight it brings to understanding the nature of leading as a relational phenomenon. Keywords: Aesthetics, Beauty, Embodiment, Leading as Artful Practice, Performance
\end{abstract}




\section{Leading Beautifully: How Mastery, Congruence and Purpose Create the Aesthetic of Embodied Leadership Practice}

Much of the leadership canon attends to behavioural aspects of leading: the leader creates and imparts a 'vision' (Bryman 1992, Drath 2001) he or she motivates and directs followers (Hersey \& Blanchard 1977, Bennis \& Nanus 1985). According to Bass (1985) he or she enables followers to achieve higher aims through transformational practices, and for adherents of 'servant leadership' (Greenleaf 1970) the leader acts as an enabler, facilitating followers' purposeful action by removing obstacles or providing necessary resources.

Rather less appears about how leaders actually enact these behavioursthe embodied way in which they attempt to motivate, direct, or transform. In fact, as highlighted by Sinclair (2005) to a large extent 'leaders' are theorised as disembodied beings. She suggests:

...although leadership has been constructed as an activity of brains without bodies...It is a bodily practice, a physical performance in addition to a triumph of mental or motivational mastery... leadership works at a visceral and sensual level, activating appetites and desires. ..The accomplishment of leadership is often highly dramatic and full-bodied; there is intimacy, titillation, sometimes mystique (387- 388). 
This paper explores the territory of leading as an embodied activity through the lens of aesthetic perception. A key assumption underpinning its argument is that the quality of a leader's performance can be judged according to its aesthetic dimension, as well as the more commonly recognised operational, symbolic, political, or moral ones. Followers perceive the elegance, awkwardness, comedy, or beauty of a leader's performance even as they judge its relevance and effectiveness. The suggestion is made that the aesthetic dimension of a leader's bearing can be particularly important in those situations in which the leader has relatively less positional power, and must rely on referent power (French and Raven 1959) instead. This possibility is highlighted as a key area for further study.

As a starting point for exploring the aesthetics of leadership practice, the paper focuses on the aesthetic category of 'the beautiful'. Hillman (1998) argues that 'beauty' is one of the most repressed and taboo concepts in our secularised and materialistic times. Certainly, within the domain of organisation studies, beauty is not a construct commonly associated with leading or leadership. Yet, quoting from Plato, Hillman argues that beauty 'reminds us of our wings, it inspires us, lifting the mind to permanent values and eternal truths.' (261) This aspiration seems to align itself with concepts such as 'charismatic' (Weber 1947) or 'authentic leadership' (Avolio and Gardner 2005). I will argue however, that although similar to these notions, 'leading beautifully' distinguishes itself from them in key ways. 
The paper explores what 'the beautiful' might mean in terms of the enactment of leadership both experientially and theoretically. It begins with a descriptive account of a leadership performance perceived as 'beautiful'. This account is then analysed and linked to idealised notions of 'the beautiful' originating in Classical Western philosophy. 'Leading beautifully' is then contrasted with similar theories in order to highlight the unique insight it contributes to our understanding of the practice of leading. By way of illustrating what might constitute 'leading beautifully', I'll begin with a story.

\section{Bobby McFerrin: A Case Study of Leading Beautifully}

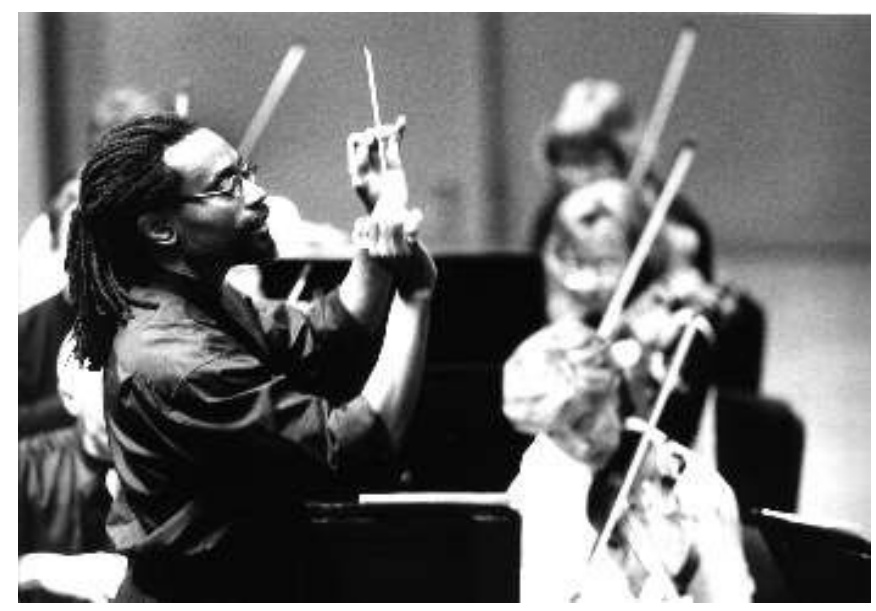

During the summer of 2005 I had the pleasure of attending Prom 32 at the Royal Albert Hall in London, which featured the a capella vocalist, Bobby McFerrin, performing in collaboration with a jazz band and the African Children's Choir. I'd attended his concert at the Proms in 2003, when he'd conducted the Vienna Philharmonic Orchestra, as well as singing the second cello part of a Vivaldi double concerto. He'd struck me then as being a particularly engaging 
performer. l'd been especially taken by how he managed to conduct the staid members of the Vienna Phil through a sung rendition of the William Tell Overture. It was a moment of sheer delight when the predominantly white-haired Austrian musicians laid their instruments on their laps and began singing their parts'oom-pahing' their way through the final chorus. I left the Hall wondering how McFerrin had achieved the level of rapport with the orchestra's members to enable them to relax their inhibitions in this way. Earlier in the performance he had orchestrated an impromptu rendition of the Salve Regina which involved the audience singing the melody while he intoned the organ part below. This had been accomplished without his uttering a word. Instead, he communicated his intent through gestures, inviting us to join him in making music as if to do so were completely natural.

During the more recent performance he performed alongside two other groups of musicians, a New York jazz band and the African Children's Choir. Again, he engaged the audience in the performance. Before l'd realised what or how it had happened, I found myself-along with the vast majority of the Hall's occupants, echoing back his vocalisations, stomping my feet and clicking my fingers in response to his gestures. How was he able to lead us in such an unobtrusive way?

We were, admittedly, a willing group. We'd all chosen to attend that particular performance, probably because of our expectation of the man and his style of performance. It was a relaxed Sunday afternoon, there was a relatively large proportion of children in the audience. Even so, having the majority of 
those present in the Royal Albert Hall responding to a flick of a wrist, and to have achieved this relationship so discretely, I found impressive.

In describing what McFerrin did, I would suggest there was more than 'effectiveness' going on. There was a quality of engagement which I experienced as 'nourishing'. McFerrin is charismatic, certainly—but his is a soft kind of charisma. I noticed how in working with his fellow musicians, he never seemed to dominate or take control of them. When he was not performing directly, he often stood at the back of the stage, nodding along to the beat. During the encore he insisted on not occupying centre stage himself, but instead, the jazz musicians and he joined the African Children's Choir in their rendition of the African Anthem. McFerrin stood in the back row, singing along to the words as he could grasp them under the direction of the young African woman who conducted the choir. I reflected on how he could lead the audience in an impromptu rendering of the Salve Regina, but in a different situation, seem just as comfortable taking the lead from someone else.

I experienced his performance as embodying a way of leading which was inclusive, accepting, and creating of a safe environment. Throughout the concert McFerrin seemed very present to the moment at hand. For instance, during one of his vocal improvisations while singing nonsense syllables, a baby in the audience began crying. I wondered whether he would respond in any way, and in a moment he did, working into his improvisation—'the baby's crying'. After a few more bars he sang, 'it will be all right, it will be all right'. The audience responded with warm laughter. He seemed to work with the present in such a 
way that I experienced now as rich ground, pregnant with potential for something new and creative to happen. This contrasts sharply with so much of the leadership literature which emphasises the leader's ability to envision the 'future'. Instead, McFerrin brought my full attention to the possibilities and potentialities of the present moment.

\section{How did he enact leadership?}

Firstly, McFerrin is a consummately skilled musician whose expertise spans a range of musical genres from jazz to classical. His mastery is attested to both by the awards he has achieved (such as an Emmy for his popular hit 'Don't Worry, Be Happy') but more importantly for the purposes of this paper-for the level of esteem granted to him by fellow musicians. The Vienna Philharmonic Orchestra is not an organisation who would easily respond to a less skilled musician at their helm.

As well as exercising mastery within the musical sphere, he demonstrated distinctive skills of communication. Much leadership literature focuses on verbal aspects of communication; getting the message 'right' in terms of its content. McFerrin never spoke to us. He communicated through gestures, vocal inflections, and the way he used his body. His body language was inclusive, there was an openness and a lack of guardedness in the way he loped around the stage.

His self presentation (on both occasions he wore black jeans and a t-shirt, in sharp contrast to the more formally attired orchestral musicians) seemed congruent with his overall style and purpose-for certainly part of his purpose 
was to disrupt us as an audience, to invite us to engage beyond the constraints of conventional performance rituals. But his style of disruption was gentle, playful and non-aggressive. It was aligned with what could be inferred as his purpose for that afternoon-to involve all of those attending his performance to join in the process of music making.

McFerrin's performance highlights for me three aspects which seem key to the enactment of 'leading beautifully':

- Mastery: both in terms of a mastery in understanding one's context and domain and mastery of the self. To be masterful in this way requires attention to the here-and-now possibilities inherent within any given moment. In this way, leading beautifully incorporates expertise.

- Coherence: expressing the self through forms which are congruent with one's overall message and purpose. This requires attending not only to what one says but the way one says it. In this way, leading beautifully incorporates authenticity.

- Purpose: attending to the goal towards which one is leading. Is the goal one that serves the best interests of the human condition? In fact, is the goal itself 'beautiful'? In this way, leading beautifully brings into play the ethical dimension of a leader's endeavor.

These aspects identified as contributing to Bobby McFerrin's leadership style find support in Classical philosophical conceptions of the beautiful. The paper now turns to explore these connections in more detail. 


\section{The Beautiful-Insights from Plato and Plotinus}

Notions of the beautiful are situated in cultural, historic and societal locations-over time, 'the beautiful' as applied to human bodies in particular has fluctuated according to taste and fashion. In considering how beauty might relate to leading, in the first instance I am posing the question, 'What is beauty?'. The philosophers Plato (428-348 BC) and the neo-Platonist, Plotinus (205-270 $A D)$ are key here, as both set out to understand the nature of beauty itself, rather than the nature of beautiful things. These philosophers' writings are also valuable to my study because their work seeks to address ' the beautiful' as expressed not only in paintings or musical compositions, but as an essence which could imbue human form as well as art works and nature. Similarly, I'm interested to tease out something of the essence of beauty which might be relevant to leadership performance.

In Carritt's (1931) landmark collection of philosophical writings about beauty, he asserts that Plato 'helps us more than later writers to make up our minds on this question (of what is beauty)' (xv). He elaborates on this writing:

Plato was convinced that it is by no linguistic accident that we call various things beautiful. We really recognize in them one common character, and this character, he thought, must be capable of definition... To Plato beauty is not just truth or edification, beauty is not a physical thing, like gold, but rather some relation of things to our minds, perhaps to our purposes (xvi) This quote highlights two important issues in considering leading through the aesthetic lens of the beautiful. Firstly, it suggests that as conceptualized by 
Plato, the experience of beauty is not just a subjective evaluation, that there is a 'common character' present in those things which we would describe as beautiful. Secondly, it suggests the relational nature of beauty, pointing out that we experience the beautiful as such because it is connected to our own minds, or purposes in a particular way. In the next section of this paper, l'll explore the first of these points, and offer suggestions from Plato and Plotinus about what constitutes the 'common character' of beauty.

It is important to note that Plato does not offer a finalized definition of beauty, but instead takes us through logical arguments in which the notion is teased out through dialogues between Socrates and various students. For instance, In Hippias Major, (1982) Plato presents Socrates interrogating Hippias about the nature of beauty. Each time Hippias arrives at an answer, Socrates poses yet another instance in which Hippias' conclusion is proven deficient. Beauty is not 'a beautiful girl', it is not the gilding of something in gold, it is not purely defined by something's usefulness, or by its 'pleasantness' from a visual or auditory perspective. Through their discussion however, key aspects of beauty are identified. The first of these is the relationship between the beautiful and the ethical.

Beauty and its Relationship to the Ethical

In order to understand the relationship Plato asserts between the beautiful and the ethical, it is important to understand one of his fundamental presuppositions, his 'Theory of Forms'. Murdoch (1992) writes that Platonic 'Forms' are 'models, archetypes: universals, general concepts as distinct from 
particular entities, and in their ethical role, (they are) moral ideals active in our lives, radiant icons, images of virtue' (10). Plato remarks on the particular power of beauty as a Form in Phaedrus (1986) when Socrates says to Phaedrus:

...but on the subject of beauty - as we said, it shone out in company with those other things, and now that we have come to earth we have found it gleaming most clearly through the clearest of our senses. For of all the sensations coming to us through the body, sight is the keenest: wisdom we do not see-- beauty alone has acquired this privilege, of being most evident and most loved (250).

Given that sight is the keenest of our senses then, Plato suggests that we are particularly attuned to those things which please our sight. But Plato's use of the word sight is more encompassing than as just a sensory experience. Plato often used the word sight as a metaphor for 'intellect' (Gosling, 2006). Thus, for Plato, the beautiful pleases not just our senses, but also our Intellect, which for Plato was itself a Form, that of 'Purified Mind'. For Plato, intellect itself is beautiful, and recognizes beauty because it is akin to itself. Plotinus notes a similar parallel between the beautiful and the soul in his Ennead I.6:

It must be therefore that, since the soul's nature is what it is, and ranks among the highest essences in the order of things, when she sees something akin to herself or even a vestige of kinship she rejoices and flutters her wings, and receives it within her, and remembers her true self and that which is hers (5). 
The link Plato makes between beauty and purified mind, and which Plotinus makes between beauty and the soul, necessitates the connection between beauty and the good. By Plato's definition, beauty cannot be used for bad ends. Plato points this out in Socrates' conversation with Hippias, when Hippias has asserted that a thing is 'beautiful' to the extent that it works efficiently and is useful. Through further discussion, Socrates asserts:

... to be beautiful it is enough for a thing to be efficient and useful. But what we meant in our hearts to say was really this, that what is useful and efficient for some good purpose is beautiful? (296) Here Plato clearly links the beautiful with the moral. In order to be beautiful, an action, or way of being must have the purpose of being good.

The link between the beautiful and the ethical carries on into contemporary philosophical writings (Moore 1903, Murdoch 1992) and can even be found within the business ethics literature. For instance Dobson (1999) argues that aesthetic development is a key path to developing virtue, and it is virtue which should act as the means by which organizational decisions are taken. He writes:

rather than economic or moral rules, what guides the manager-as-artisan is the pursuit of internal goods; the nurturing of the aesthetic relation (163). Likewise, I am arguing here that 'leading beautifully' incorporates aiming towards ethical purposes. However, here I am similarly taking a Classical view of 'ethics', one that is grounded in notions of 'the good life' and 'human flourishing', rather than strict adherence to rule-based norms. From this standpoint, leading beautifully could be seen as an ethical aim in itself. This raises the question of how leading 
beautifully is created, and a starting point is the connection between the purpose one has, and the way in which it is embodied.

Fitness of Purpose

According to many Classical philosophers, beauty arises when there is congruence between an entity's or act's purpose and how that purpose is embodied. The following passage from Hippias Major (1982) elaborates on this, as Socrates and Hippias discuss Pheidias' representation of Athene,

S: (Pheidias was a good artist, but) he did not make Athene's eyes of gold, nor the rest of her face, nor the hands and feet, but of ivory, though gold would have made her look more beautiful. And this mistake must have been due to his ignorance of the fact that, as you say, it is gold which gives beauty to everything. What are we to say, Hippias?

$\mathrm{H}$ : Nothing very difficult. We shall say that Pheidias was quite right. For I suppose ivory is beautiful too.

S: But why did he work the eyeballs not in ivory but in stone, exquisitely matching the stone to the ivory. Or is beautiful stone beauty too? $\mathrm{H}$ : In its right place, we must agree that it is.

S: Then, does your wisdom come to this, that ivory and gold make things beautiful when they are appropriate, but otherwise ugly? (289) In an earlier version of Socrates' philosophy, Xenophon (430-350 BC) presents a dialogue between Socrates and Aristippus in which they come to agreement that even a 'dung basket' can be a beautiful thing, if it is beautifully fitted to its purpose (Xenophon 1990). 
Likewise, this suggests that a key aspect of leading beautifully will be determined by the extent to which the leader acts in a way which 'fits' his or her purpose. For example, consider a leader who might not be thought of as conventionally 'beautiful', such as Mo Mowlam, the former British Minister of Parliament who held a pivotal leadership role in the Northern Ireland peace process. A legendary story of Ms Mowlam's involvement with that process tells of how, at a particularly crucial point in the negotiations, she removed her wig (which she'd been wearing having lost her hair due to chemotherapy treatments) and began thumping it on the table to reinforce her point. Conventional ideas might not judge this a beautiful act, but perhaps, given the context within which she was working, it ideally fit her purpose.

Additionally, it was behavior which was not out of keeping with Mowlam's reputation as an outspoken, unconventional politician. Her act was congruent with both the immediate moment, and with how she was known to be. In that way, it could be seen to be authentic_-it 'rang true' to the others present at the meeting. It is also the moment which is mythologised as catalyst for breaking the deadlock in the negotiations. Perhaps it also reflects Ms Mowlam's expertise at reading the situation, which indicates a third aspect of leading beautifully, 'mastery'.

Mastery

Here, the notion of mastery is explored from two different angles, firstly, how mastery connects with ideas of 'form', and secondly, how it fits with ideas of 'measure'. Throughout Classical writings philosophers refer to beauty being the 
result of harmonious 'form'. An entity, or an act, is beautiful because it adheres to a particular 'form', one which is harmonious, symmetrical and pleasing. For instance, Plotinus comments in distinguishing between the beautiful and the ugly, that those things which are beautiful adhere to a certain 'form' or 'reason':

'the beautiful' is created through the harmonious proportion of parts to each other and the whole thing must have pleasing coloring (1984:4). He further asserts that we can tell the difference between the beautiful and the ugly by reference to the way each relates to form:

'the ugly is that which is not dominated by its form and reason, when its matter will not allow it to be completely molded to its form. (Plotinus 1984: $5)$. In considering leading beautifully, the notion of 'form' might relate to mastery within the domain in which a leader operates. Bobby McFerrin, for instance, is a master at the 'form' of creating music. He is so expert within the form that he can attend carefully to the sphere within which he is performing, and express the form in the most fitting way for a specific context. Likewise, once organizational leaders have mastered a functional domain, they can turn their attention to discerning how their expertise might be best used within a given situation.

Mastery from a leadership perspective might also extend to other, more contextually-based areas of domain competence. For instance, a leader may have mastered the reading of organizational politics, or may be particularly expert at building strong relationships with key stakeholder groups. 
A second aspect of such mastery discussed by both Plato and Plotinus concerns 'measure'. This is about knowing 'how much' of a certain act is beautiful, as opposed to being either stingy or excessive. Making such a judgment requires attention to the present, for only accurate reading of the here and now can alert someone to what might constitute the appropriate measure in a given moment.

In his Dialogue 'The Statesman', Plato (1995) elaborates on this idea, writing:

'When a maker commands his art he can judge the excellence of his product according to his insight into proportion and measure.

Fundamentally then, the artist must, if he is to work well, know the nature of Measure. For to know the proper length of a speech, the proper proportion of a painting, the proper distribution of functions in a society, the proper organization of a poem, is to command the art of measurement.' (285)

Hofstadter and Kuhns (1964: 4) suggest that for Plato, 'measure' embraces the principles of the good and the beautiful' and knowing the measure of something is essential to producing it beautifully. Such a sensibility could be appreciated as a key feature of mastery, of knowing what, in a particular circumstance, is the 'right' amount of interaction, the length of the speech, the loudness of the crescendo. Acting on such discernment differentiates between actions or intonations which are fitting, which add to the overall shape and form of a performance, and those acts which are distracting and detracting. 
Here, then, I am suggesting that leading beautifully demonstrates mastery at two levels. Firstly, the leader exhibits expertise within a 'form'-that form may be a field of professional expertise, such as McFerrin's musical mastery, or it may be mastery of a particular skill, such as influencing others or building relationships. Secondly, leaders who lead beautifully are attentive to how 'much' of a certain action, or gesture, or communication is necessary. Sometimes, paradoxically, leading beautifully requires minimal, rather than maximum action, as illustrated by the following story.

In exploring ideas of leading beautifully, a manager spoke about attending a conference in Atlanta, Georgia to hear Warren Bennis. The day in question was hot and humid and the air conditioning had broken down in the room in which Bennis was speaking. Sitting in the audience was uncomfortable and there was a good deal of fidgeting and shuffling during the opening minutes of Bennis's talk. About twenty minutes into the presentation, Bennis paused. 'This isn't going very well is it?' he asked the crowd. There were muffled noncommittal replies. 'Well, what should I do?' he asked. Someone suggested, 'turn the mic over to us.' Bennis did so. The group proceeded to self-organize into smaller work groups, distribute themselves throughout cooler rooms in the building, and accomplish a good afternoon's work. The teller of the story recounted how he felt this was 'beautiful' on Bennis's part, that it was an apt and skilled response to the circumstances. What particularly impressed the teller was that Bennis was able to relax his own ego concerns and provide the space for the group to decide how best to use the time. Paradoxically, choosing not to 
continue speaking demonstrated, at least to this observer, Bennis's mastery as a speaker.

Such mastery, along with congruence between an act's form and its purpose weave through both the experience of 'beauty' and the way it has been conceptualized by Plato and Plotinus. The paper now moves on to consider how leading beautifully compares with other leadership theories which occupy similar territory.

\section{Leading Beautifully_-Adding New Insight to Existing Theory?}

Although the aesthetic dimension of organizational dynamics is a relatively new departure (Gagliardi 1996, Linstead and Hopfl 2000, Strati 1999,) there is little writing devoted specifically to the aesthetics of leadership (Duke 1986) or more particularly to what leading beautifully might entail. However, there are a number of theories which offer similar ways of thinking about leading and leadership, including:

- Leading as a performing art

- Charismatic leadership

- Authentic leadership

- Impression management

Each is contrasted with 'leading beautifully' in the following section of the paper. Leading as a Performing Art

Grint (2000) suggests that leadership should be considered more of an art-form than a science, and highlights four particular art-forms which it emulates: the philosophical arts, the fine arts, the martial arts, and finally, the performing 
arts. The performing arts take into account the way things are said, including aspects such as gesture and tonal inflection as well as the use of symbols to convey meanings. Grint argues that the performative dimension of leading moves the hearts and minds of followers.

Although Grint makes the case for the importance of this performative dimension, he does little to map the territory or explain how effective performances are created. The notion of leading beautifully l'm offering here could be seen to build on Grint's work in attempting to articulate particular aspects (mastery, congruence, and purpose) which contribute to the performance dimension

\section{Charismatic Leadership}

Undoubtedly, leading beautifully can be experienced as charismatic. Ladkin (2006 ), writes about possible linkages between the charismatic and the 'sublime' aesthetic experience. A key point made in that writing is that in both Weber's theorization of charisma (1947), and Kant's theorization of the sublime (2005) , there is a recognition of a 'negative pleasure' associated with each experience. The sublime cannot be wholeheartedly embraced without a concurrent experience of discomfort. Likewise, Weber (1947) suggests that in the engagement with a charismatic leader, the follower experiences a loss of self, a kind of obliterating of one's individual identity, which is not an altogether pleasant experience. In contrast to this, philosophers through the ages have noted how the experience of the beautiful can be wholeheartedly enjoyed without discomfiture or unease (Kant 2005, Burke 1990, Scarry 1999). 
Furthermore, charisma can operate in such a way that the follower loses his or her own sense of identify through identification with the leader. Instead of being a soul-affirming experience, engagement with extreme versions of charisma can veer into the soul-destroying, as witnessed by the 'shadow side' of charismatic power (Kets de Vries 2004). Charismatic leaders can align their purposes to self-serving and harmful ends, whereas for leading to be beautiful, I am arguing it must be in the aid of the best of human purposes. The ethical requirement of leading beautifully also differentiates it from another perceptual dynamic, impression management.

\section{Impression Management}

The charismatic has been linked to a third area of literature which intersects the notion of leading beautifully, 'impression management'. Sosik, Avolio and Jung (2002) outline the components of impression management and present evidence indicating that certain behaviors charismatic leaders engage in can be seen to increase the chances that followers will attribute charisma to them.

An example of how effective leaders manage their images can be seen in Richard Branson, who writes openly in his recent autobiography (Branson 2005) about the role impression management played in the establishment of the Virgin brand. For instance, Branson reveals that in the early days of running Virgin, he would regularly use pay telephones when calling important clients. He would ring the operator, claiming he'd lost his money in the phone, which then required the operator to connect the call. On being transferred, the operator would inevitably 
say to the person answering the call, 'I have Mr Branson for you', thereby creating the impression that Branson had a PA dedicated to placing his telephone calls. Similarly, when speaking on the telephone to potential clients, he would arrange for someone to call out from the other side of the office 'Ted Heath is on the other line wanting to talk with you,' thus suggesting that Branson interacted with well-placed figures in the British government.

Although such behaviors may portray a favorable impression, their deceitful element would preclude their falling within the definition of leading beautifully I am offering here. Jones \& Pittman (1982) suggest this type of self promoting impression management is often used at another's expense, a tactic which demotivates followers in the long run. This raises an important aspect of both impression management and the perception of a leader's aesthetic: in each case it is the follower who ultimately has the impression, or judges the aesthetic.

The distinction between the impression an individual aims to produce, and how onlookers actually read a given behavior is captured by the distinction Goffman (1959) makes between the impression a person 'gives' and that which she or he 'gives off'. Although an individual can control what they 'give', i.e. Branson decided to behave in certain ways to try to create a certain impression; he or she cannot control what is 'given off', i.e. the sense onlookers make of the behaviors. This dynamic aspect of perception is a key feature of leading beautifully, and also features largely in the experience of 'authentic leadership', explored in greater detail below.

Authentic leadership 
In the wake of corporate misbehaviors such as those exemplified by Enron, Shell and Worldcom, a burgeoning literature has grown focused on 'authentic' leadership. Shamir and Eilam (2005) suggest that although there are a number of differing definitions of authentic leadership, the link between the leader's values and behaving ethically is at the heart of the majority of this literature. From this perspective, authenticity is determined over time, as followers judge the extent to which a leader acts consistently, reliably takes certain stances, and behaves in accordance with organizational and societal norms.

I'm suggesting here that authenticity also operates aesthetically, and as such will be determined very quickly. For instance, followers 'get a sense' of whether or not a leader is trustworthy from their 'gut reaction' to that leader. By reading those seemingly invisible clues embodied in a leader's stance, facial expressions, bodily tension and tone of voice followers draw conclusions about a leader's motives, hidden agendas and unconsciously, as well as consciously expressed purposes. These difficult to quantify aspects of a leader's performance are gathered at a preverbal level of apprehension and create the leader's affective aesthetic. They add up to whether or not a follower 'reads' a leader's performance as authentic.

Earlier in the paper authenticity, as the felt sense to which a leader was expressing views coherent with their beliefs, was identified as an aspect of leading beautifully. What the notion of leading beautifully adds to the current literature about authentic leadership is the idea that authenticity is aesthetically 
determined, as well as being an attribute followers ascribe to leaders if they act in accordance with their espoused values, in a consistent manner over time.

In summary, considering the aesthetic dimension of leadership pushes extant theory by bringing into high relief the performative element of leading, and articulating key aspects of that performance. Moving beyond charismatic leadership, in order to be considered 'beautiful' aesthetically, leading must be directed towards life enhancing purposes. Finally, 'leading beautifully' offers 'authentic leadership' an explanation for those split-moment apprehensions of a leader's authenticity. This last point alludes to the relational aspect of aesthetic appreciation, a point elaborated on below.

\section{Leading Beautifully_-Effects on Followers}

The most elegant leadership performance in the world will not have the desired affect if followers are more concerned with their well-being or their physical comfort than paying attention to the leader. I am certain there are many people who attended the Bobby McFerrin concert who did not perceive the beauty of the man's style as I did. Some would have been distracted by the incongruity of McFerrin in that particular setting, or would have been too preoccupied by their own concerns to have registered an aesthetic apprehension. Others would have interpreted his performance differently from the way l've presented it here. However, I was led to believe that other audience members had experienced similar delight to my own by the comments I overheard and the generally relaxed and cheerful demeanor of those I passed as I left the Hall. 
Something had passed between McFerrin and his audience that day. Something had evoked our willing response.

I'm attributing that something to the way McFerrin engaged with us, a way I have characterized as 'beautiful'. Interrogating this dynamic as done within this paper could yield important clues for leaders who find themselves in similar situations to McFerrin's; in which they have little positional or hierarchical power, little in the way of coercive or reward power, and where the ability to persuade and engage followers is generated primarily through personal power.

Two theories might help deconstruct this dynamic further. The first is 'Leader-member exchange theory' (LMX) (Dansereau, Graen and Haga 1975, Graen and Cashman 1975). A key concept within LMX theory is that leaders form particular relationships with followers, resulting in 'in-groups' and 'outgroups' within the organization. Although those operating within in-groups may suffer from jealousy due to the favoritism they enjoy, it has been shown that 'in groups' do perform at higher than average levels of productivity and success, indicating that the creation of 'in groups' can be beneficial to organizational performance (Graen and Uhl-Bien 1995).

One of the aspects which might influence the attractiveness of a leader for a follower to become part of the leader's in-group, is the particular aesthetic of that leader. Along with benefits, 'in-group' membership also yields disadvantages such as the expectation of longer work hours and increased pressure to perform at exceptional levels. Part of the inter-personal glue which holds devoted followers could be attraction of the leader's mastery, their 
adherence to ideals, or the purpose for which they stand. Although such aspects may be hard to quantify, they could contribute to the mix which produces exemplary organizational performance.

A second theory which offers insight into the role of beauty in interpersonal perception is that produced by Rowe about the impact of what she called 'micro-inequalities' and 'micro-affirmations'. Micro-affirmations are the discreet behaviours that offer encouragement and bring out the best in people (Rowe, 1990). They are gestures as small as holding another's glance, nodding when they are speaking, or literally patting them on the back, which demonstrate acceptance and approval. These are not actions which can be parroted and still be experienced as authentic. Linking the performance of micro-affirmations back to the notion of leading beautifully, they must be enacted in a way which is congruent to the leader's style, and to the right measure, in order to be perceived as being authentic and potentially beautiful. However, when I reflect on what McFerrin DID to create the experience of leading beautifully, it was the small, open gestures, the willing and unforced smile, the way he easily draped an arm around a young African child's shoulders, which coalesced my apprehension of his performance as beautiful.

These two frameworks offer potential theoretical starting points for further examination of how leading beautifully might both be perceived by followers, and contribute to the leader-follower dynamic. For instance, it would be of potential interest to explore whether 'in-group' members perceive the leader to generate an aesthetic quality to which they are drawn, and whether or not there is a shared 
(but perhaps tacit) appreciation of that aesthetic among in-group members.

Similarly, attending to micro-gestures and how they are perceived might help to build our understanding of the aesthetic of leading from an experiential base.

Both LMX and Rowe's work highlight the relational aspects of leading by drawing attention to the effect of a leader's way of being on followers. Likewise, the significance of a beautiful performance, whether it is a leadership performance or an orchestral concert, is in its impact on those beholding it. Leading beautifully is important, I propose, because it has the potential to move followers in ways that other embodied aesthetic forms cannot. Exploring this conjecture is a key focus for future research.

\section{Limitations and Areas for Further Research}

Here, I have used the case study of Bobby McFerrin as a starting point for exploring what might be meant by leading beautifully. Of course, a myriad of difficulties arise from treating one case study in this way, including: the singularity of my perception, my own biases and background which will have effected how I experienced the performance, the impossibility of generalizing from a sole experience. However, in comparing my analysis of his performance with Classical views of what constitutes beauty, similar themes have arisen. Additionally, there seems to be a high degree of recognition of the phenomenon of leading beautifully when I discuss its possibility with students and colleagues. It is often recognized as a qualitative aspect of the leadership dynamic which is rarely articulated. 
This may be partly to do with the 'taboo' associated with discussing beauty in contemporary times. Perhaps this is because of beauty's power, the power to arouse desire, to seduce, to sway hearts. Yet such power might have a particular role to play in leadership dynamics where hierarchical power is absent-where a leader must resort to his or her ability to persuade by force of personal power. Considering such relationships from the aesthetic perspective might bring unique insights into how they work, highlighting, perhaps, the role of pleasure, as well as desire in leader/follower relations. These areas, along with the following questions, provide rich ground for further inquiry:

- Do leaders who are experienced as 'leading beautifully' evoke distinctive responses from their followers? Could leading beautifully be seen to be more effective, for instance, than leading in a way characterized as 'ugly' by one's followers?

- How much does the experience of 'beautiful leadership' rely on the sensibilities of followers to discern it as beauty—would nonmusicians, for instance, have been as aware of McFerrin's level of mastery?

- What circumstances does leading beautifully most fit-are there situations in which 'ugly leadership', for instance, might be more effective?

- If a leader aspires to leading beautifully, what must he or she pay attention to? Is leading beautifully something that can be 
developed or does every leader need to find and express his or her own aesthetic in order to be authentically perceived?

\section{Conclusion}

To consider anything beside art from an aesthetic perspective is relatively alien to our contemporary Western way of conceptualizing the world. Taylor (2002) in his study of organizational aesthetics writes of 'aesthetic muteness'the outcome of his research which indicated that people in organizations don't have the language to talk about the qualitative aspect of their experience. Yet, the difficulty experienced in articulating this domain of sensory experience does not mean it has no impact on inter-relationships between leaders and followers.

The concept of 'leading beautifully' brings our attention to that often unarticulated, but nonetheless powerful aspect of how leaders embody their role. Leading beautifully speaks to a quality of being-one honed through the development of self-mastery, and quickened through the congruence of one's acts with their 'measured' expression. It also alerts us to the possibility of a leader's goals being directed towards the best of human purposes.

Theoretically, 'leading beautifully' may have a more general application as well. Plato suggests that what is beautiful in a runner will not be beautiful in a wrestler (1982: 295), meaning that when we appreciate something as beautiful, we are apprehending something of the essence of the act which they are performing. Similarly, by noticing what constitutes a beautiful leadership performance, perhaps we can be informed of the essence of leading itself. 
Though rarely written about, leading beautifully has occurred as long as human beings have been acting together to create our communities, institutions, and culture. By bringing this qualitative aspect of leading to the fore, it is hoped that both leaders and those who follow them might become more attentive to beauty, as well as other aesthetic responses, and value those responses for the sensory, spiritual and moral knowledge with which they are invested. 


\section{References}

Avolio, B.J. \& Gardner, W.L. (2005). Authentic leadership development: Getting to the root of positive forms of leadership. The Leadership Quarterly, 16, 315-338.

Bass, B.M. (1985). Leadership and performance beyond expectations. New York: Free Press.

Bass, B. M. \& Avolio, B. J. (1994). Improving organisational effectiveness through transformational leadership. Thousand Oaks, CA: Sage.

Bennis, W. \& Nanus, B. (1985). Leaders: The Strategies for taking charge. New York: Harper and Row.

Branson, R. (2005). Losing my virginity: The Autobiography. London: Virgin.

Burke, E. (1990). A Philosophical enquiry into the origin of our ideas of the sublime and beautiful. Oxford: Oxford University Press.

Bryman, A. (1992). Charisma and leadersip in organszations. London: Sage.

Burns, J.M. (1978). Leadership. New York: Harper \& Row.

Carritt, E. F. (1931). Philosophies of beauty: From Socrates to Robert Bridges. Oxford: Clarendon Press.

Dansereau, F., Graen, G.G., \& Haga, W. (1975). A vertical dyad linkage approach to leadership in formal organizations. Organizational Behaviour and Human Performance, 13, 46-78.

Dobson, J. (1999). The Art of managing and the aesthetic manager-Managing the coming way of business. Westport, CT: Quorum Books. 
Drath, W. (2001). The Deep blue sea: Rethinking the source of leadership, San Francisco: Jossey-Bass.

Duke, D.L. (1986). The Aesthetics of leadership. Education Administration Quarterly, 22 (1) 7-27.

French, J.R., \& Raven, B.(1959). The Basis of social power. In D.Cartwright (Ed.), Studies in social power (pp.150-167). Ann Arbor: Institute for Social Research, University of Michigan.

Gagliardi, P. (1996). Exploring the aesthetic side of organisational life. In S. R. Clegg, C. Hardy \& W. R. Nord (Eds.), The Handbook of organisational studies (pp 565-580). London: Sage.

Goffman, E. (1959). The Presentation of self in everyday life. Garden City, New York: Andover.

Gosling, J. (2006) personal communication.

Graen, G. B., \& Cashman, J. (1975). A role-making model of leadership in formal organizations: A developmental approach. In J. G. Hunt \& L. L. Larson (Eds.) Leadership Frontiers (pp 143-166). Kent, OH: Kent State University Press.

Graen, G. B., \& Uhl-Bien, M. (1995). Relationship-based approach to leadership: Development of leader-member exchange (LMX) theory of leadership over 25 years: Applying a multi-level, multi-domain perspective. The Leadership Quarterly, 6(2) 219-247.

Greenleaf, R. (1970). Servant as leader. Center for Applied Studies.

Grint, K. (2000). The Arts of leadership. Oxford: Oxford University Press. 
Hersey, P. \& Blanchard, K. (1977). Management of organizational behaviour. Englewood Cliffs, NJ: Prentice Hall.

Hillman, J. (1998). The Practice of beauty. In B. Beckley \& D. Shapiro (Eds.), Uncontrollable beauty: Towards a new aesthetics (pp 261-274). New York: Allworth Press.

Jones, E. E. \& Pittman, T.S. (1982). Toward a theory of strategic selfpresentation'. In J.Suls (Ed.), Psychological perspectives on the self (pp. 231-262). Hillsdale, NJ: Erlbaum.

Kant, I. (2005) Critique of judgment. J.H.Bernard (Trans.), Mineola, N.Y.: Dover Publications.

Kets de Vries, M. (2004). Lessons on leadership by terror: Finding Shaka Zulu in the attic. Cheltenham, UK: Edward Elgar Publishers.

Ladkin, D. (2006). The Enchantment of the charismatic leader: Charisma reconsidered as aesthetic encounter. Leadership, 2/2, 165-180.

Linstead, S. \& Hopfl, H. (2000). The Aesthetics of organization. London: Sage. Moore, G.E. (1903). Principia ethica. Cambridge: Cambridge University Press. Murdoch, I. (1992). Metaphysics as a guide to morals. London: Chatto \& Windus.

Plato (1982). Hippias Major. P Woodruff (Trans), Oxford: Blackwell. Plato (1986). Phaedrus. C.J.Rowe (Trans.), Warminster, UK: Aris \& Phillips. Plato (1995). Statesman. J Annus \& R Waterford (Eds.) Cambridge: Cambridge University Press. 
Plotinus (1984). Plotinus on the beautiful: Ennead 16. T. Taylor (Trans),

Godalming, Surrey: The Shrine of Wisdom.

Rowe, M. (1990) Barriers to equality: The Power of subtle discrimination to maintain unequal opportunity. Employee Responsibilities and Rights, 3/2, 153-163.

Shamir, B., \& Eilam, G. (2005). "What's your story?" A Life-stories approach to authentic leadership development. The Leadership Quarterly, 16, 395417.

Sinclair, A. (2005). Body possibilities in leadership. Leadership, 1/ 4, 387-406.

Sosik, J. J., Avolio, B,, \& Jung, D.I. (2002). Beneath the mask: Examining the relationship of self-presentation attributes and impression management to charismatic leadership. The Leadership Quarterly, 13, 217-242.

Strati, A. (1999). Organization and aesthetics. London: Sage.

Taylor, S. (2002). Overcoming aesthetic muteness: Researching organizational members' aesthetic experience,. Human Relations, 55/7, 821-840.

Weber, M. (1947). The Theory of social and economic organization. T Parsons (Trans). New York: Free Press.

Xenophon (1990). Conversations of Socrates. H. Tredennick \& R. Waterfield (Eds.) London: Penguin. 


\section{ACKNOWLEGEMENTS}

The author wishes to acknowledge Professor Jonathan Gosling, Dr Robin Ladkin and Dr Steven Taylor, along with two anonymous reviewers for the helpful comments they made on earlier drafts of this article. 